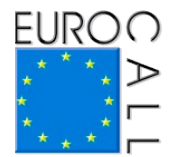

\title{
VISP 2.0: methodological considerations for the design and implementation of an audio- description based app to improve oral skills
}

\author{
Ana Ibáñez Moreno ${ }^{1}$ and Anna Vermeulen ${ }^{2}$
}

\begin{abstract}
In this paper the methodological steps taken in the conception of a new mobile application (app) are introduced. This app, called VISP (Videos for Speaking), is easily accessible and manageable, and is aimed at helping students of English as a Foreign Language (EFL) to improve their idiomaticity in their oral production. In order to do so, the app invites the user to make the Audio-Description (AD) of a clip, as part of a communicative task. This paper gives an account of the processes followed after creating and testing VISP, until arriving at the conception of its second version, VISP 2.0. This was accomplished by carrying out several empirical tests to evaluate the app and the learning outcomes it contributes to achieve. The data obtained to date have led to the proposal of some pedagogical guidelines that can be applied to a Mobile-Assisted Language Learning (MALL) app in order to make it enjoyable and, above all, effective.
\end{abstract}

Keywords: language learning, audio-description, speaking, MALL.

\section{Introduction}

Keeping in mind the idea of making audiovisual products accessible to visually impaired people, from the 1970s some films began to be audio-described. This means that, taking the gaps between dialogues, visual information is described orally. Interesting studies (Bourne \& Jiménez Hurtado, 2007, for instance) have

1. Universidad Nacional de Educación a Distancia (UNED), Spain; aibanez@flog.uned.es

2. Ghent University, Belgium; anna.vermeulen@ugent.be

How to cite this article: Ibáñez Moreno, A., \& Vermeulen, A. (2015). VISP 2.0: methodological considerations for the design and implementation of an audio-description based app to improve oral skills. In F. Helm, L. Bradley, M. Guarda, \& S. Thouësny (Eds), Critical CALL - Proceedings of the 2015 EUROCALL Conference, Padova, Italy (pp. 249-253). Dublin: Research-publishing.net. http://dx.doi.org/10.14705/rpnet.2015.000341 
shown the pedagogical benefits of this new mode of audiovisual translation, called audio-description (AD).

Additionally, in recent years $\mathrm{AD}$ has been applied in the face-to-face foreign language (FL) classroom (Ibáñez Moreno \& Vermeulen, 2014), as well as in CALL (Talaván \& Lertola, 2013) to improve students' competences, with positive results. In order to contribute to this new line of research, we have implemented AD as a tool to promote oral production skills with mobile devices (android operating systems). We designed a MALL application named VISP (VIdeos for SPeaking), which invites users with a B1 level of English (CEFR, 2001) to audio-describe a short film clip. The main aim of this app is to improve their idiomaticity (fluency, vocabulary, phraseological competence).

In this paper we outline the methodological steps which led to the creation of the second version of VISP, once the first version had been tested with Spanish and Belgian (Dutch speaking) EFL students at Universidad Nacional de Educación a Distancia (UNED) -VISP 1.1 - and at Ghent University (Belgium) -VISP 1.2. Taking into account the data obtained from the pre-questionnaire, the recordings and the post-questionnaire, we address the shortcomings of VISP 1 at different levels, which have been solved in VISP 2.0.

\section{Method}

\subsection{Methodological preliminaries}

VISP is conceived as a MALL app to be used ubiquitously in order to enhance the oral competences of EFL students. It has been designed in the framework of the communicative approach to language teaching and learning and follows the CEFR (2001) levels. Even if ubiquitous learning environments have increased and new technologies have been developed to adapt to the new learning styles, we believe that there are fewer chances for the average user, in this context, to practice oral production. In this sense, $\mathrm{AD}$ has proved to be a useful tool to promote oral skills in the FL classroom (Ibáñez Moreno, \& Vermeulen, 2014), but it had not yet been tested in MALL. Therefore, VISP is the first AD-based MALL-app.

Within the philosophy of the communicative approach there are several methods and techniques. In this application we use the task-based approach, in the sense that VISP consists of communicative tasks whose goal is to achieve a specific learning objective (Ellis, 2003). 


\subsection{Conception of VISP}

VISP has four screens, as seen in Figure 1 below.

Figure 1. Home screen of VISP

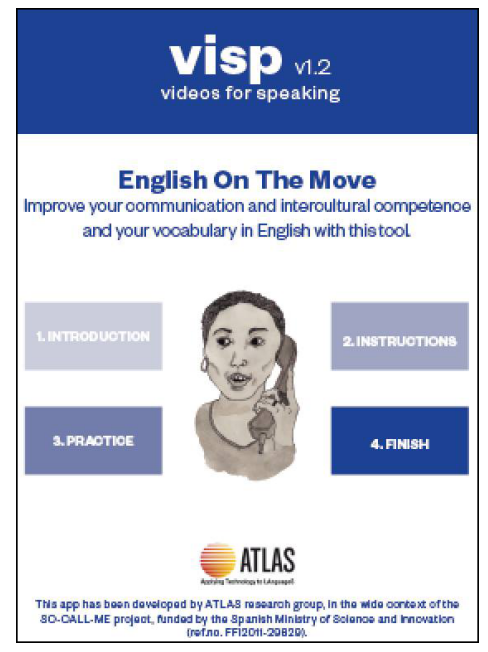

The first button, Introduction, includes a five-second sample of an AD, extracted from Memoirs of a Geisha, as a warming-up listening task. At the bottom of the Introduction page there is also a link to a pre-questionnaire, where users can complete a short test, which includes language content that will appear on the AD task and therefore on the $\mathrm{AD}$ script. The second button is the Instructions screen. The next step is the Practice screen, where the main task is found. There, users find 30-second-clips that they have to AD. Users can watch the clips as many times as they want, by clicking on Play and Rewind, until they feel ready to record their own AD (by clicking on Record). Once users are satisfied with their AD they go to the Finish screen. There they send their recording to an e-mail account. This screen also includes a self-evaluation section in the form of a post-questionnaire where they can watch the original clip with the oral $\mathrm{AD}$, as well as the written original $\mathrm{AD}$ script, and compare their own $\mathrm{AD}$ to it.

\section{Discussion}

By now, a total of 22 students have tried the app: 12 Spanish students and 10 Belgian students. Two of the Spanish students were UNED students following a CALL course on English for Tourism, and the other 10 were on an Erasmus stay 
at Ghent University (Belgium). All participants had a B1 level of English (in terms of the CEFR). They all performed the main and essential part of the task, that is, the creation of the AD, and sent their recordings. As for the pre-questionnaire and the post-questionnaires, all Spanish students filled them in, whereas only two of the Belgian students took the time to complete them. The Spanish students also left some comments and (positively) rated the app.

The analysis of the transcriptions, in terms of accuracy, illustrated a significant difference between the groups: the two UNED Spanish students and the 10 Belgian students performed slightly more accurately than the 10 Spanish Erasmus students. When it came to self-evaluating their description of actions, however, the Spanish Erasmus students felt remarkably positive about how they had described what the character does. However, there is a discrepancy between these students' perception of what they say they described and the way they described it. In terms of the students' attitudes towards the app, measured through the questionnaires, the results show that all the Spanish students were more open and positive towards VISP than their Belgian counterparts. Also, the Spanish students rated VISP more positively, while the two Belgian students were more critical.

\section{Conclusions}

In the light of all the results described, in VISP 2 we observed the need to implement several changes. As regards the attitudinal contents, even if thanks to the postquestionnaires users can make the $\mathrm{AD}$ task a really effective one and assess whether their learning goals have been achieved, not all users like questionnaires and are so open for them. The Belgian users, who come from a more individualistic society (in pragmatic terms, as in Goethals \& Depreitere, 2009), did not complete them. Therefore, our future work is in the line of giving alternative options to those users who do not find questionnaires attractive, and of designing the questionnaires in a different way so that they can also capture the attention of all users. As for procedural contents, in VISP 2.0 the post-questionnaire has been designed so as to more accurately assess the users' performance. That way, they will be able to analyse their own results in a more realistic way.

\section{Acknowledgements}

We would like to thank the Spanish Ministry of Science and Innovation, because this paper is funded through the Grant FFI2011-29829: Social Ontology-based Cognitively Augmented Language Learning Mobile Environment (SO-CALL$\mathrm{ME})$. 


\section{References}

Bourne, J., \& Jiménez Hurtado, C. (2007). From the visual to the verbal in two languages: a contrastive analysis of the audio description of The Hours in English and Spanish. In J. Díaz Cintas, P. Orero, \& A. Remael (Eds), Media for All (pp. 175-187). Amsterdam: Rodopi.

CEFR. (2001). Common European framework of reference for languages: learning, teaching, and assessment. Cambridge: Cambridge University Press and the Council of Europe.

Ellis, R. (2003). Task based language learning and teaching. Oxford: Oxford University Press.

Goethals, P., \& Depreitere, L. (2009). SpreekTaal: un proyecto didáctico y de investigación acerca de las funciones comunicativas. Mosaico, 21,14-18.

Ibáñez Moreno, A., \& Vermeulen, A. (2014). La audiodescripción como técnica aplicada a la enseñanza y aprendizaje de lenguas para promover el desarrollo integrado de competencias. In R. Orozco (Ed.), New directions on Hispanic linguistics (pp. 263-292). Baton Rouge: Cambridge Scholars Publishing.

Talaván, N., \& Lertola, J. (2013). Audiodescription and foreign language education: new approaches. Paper presented at the 5th International Conference of Media for All association, Audiovisual translation: Expanding Borders, Dubrovnik, Croatia. 


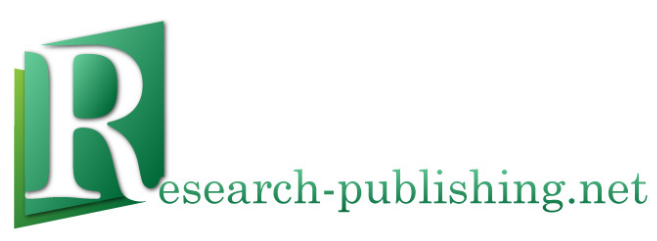

Published by Research-publishing.net, not-for-profit association Dublin, Ireland; info@research-publishing.net

(C) 2015 by Research-publishing.net (collective work)

(C) 2015 by Author (individual work)

Critical CALL - Proceedings of the 2015 EUROCALL Conference, Padova, Italy Edited by Francesca Helm, Linda Bradley, Marta Guarda, and Sylvie Thouësny

Rights: All articles in this collection are published under the Attribution-NonCommercial -NoDerivatives 4.0 International (CC BY-NC-ND 4.0) licence. Under this licence, the contents are freely available online (as PDF files) for anybody to read, download, copy, and redistribute provided that the author(s), editorial team, and publisher are properly cited. Commercial use and derivative works are, however, not permitted.

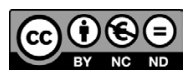

Disclaimer: Research-publishing.net does not take any responsibility for the content of the pages written by the authors of this book. The authors have recognised that the work described was not published before, or that it is not under consideration for publication elsewhere. While the information in this book are believed to be true and accurate on the date of its going to press, neither the editorial team, nor the publisher can accept any legal responsibility for any errors or omissions that may be made. The publisher makes no warranty, expressed or implied, with respect to the material contained herein. While Research-publishing.net is committed to publishing works of integrity, the words are the authors' alone.

Trademark notice: product or corporate names may be trademarks or registered trademarks, and are used only for identification and explanation without intent to infringe.

Copyrighted material: every effort has been made by the editorial team to trace copyright holders and to obtain their permission for the use of copyrighted material in this book. In the event of errors or omissions, please notify the publisher of any corrections that will need to be incorporated in future editions of this book.

Typeset by Research-publishing.net

Fonts used are licensed under a SIL Open Font License

ISBN13: 978-1-908416-28-5 (Paperback - Print on demand, black and white)

Print on demand technology is a high-quality, innovative and ecological printing method; with which the book is never 'out of stock' or 'out of print'.

ISBN13: 978-1-908416-29-2 (Ebook, PDF, colour)

ISBN13: 978-1-908416-30-8 (Ebook, EPUB, colour)

Legal deposit, Ireland: The National Library of Ireland, The Library of Trinity College, The Library of the University of Limerick, The Library of Dublin City University, The Library of NUI Cork, The Library of NUI Maynooth, The Library of University College Dublin, The Library of NUI Galway.

Legal deposit, United Kingdom: The British Library.

British Library Cataloguing-in-Publication Data.

A cataloguing record for this book is available from the British Library.

Legal deposit, France: Bibliothèque Nationale de France - Dépôt légal: décembre 2015. 